\title{
DZIECKO NIEPEENOSPRAWNE JAKO OFIARA PRZESTĘPSTW SEKSUALNYCH, Z UWZGLĘDNIENIEM ZABURZEŃ ODŻYWIANIA PO TRAUMIE - PRZEGLĄD PIŚMIENNICTWA
}

\author{
DISABLED CHILD AS A VICTIM OF SEXUAL CRIMES, INCLUDING EATING DISORDERS AFTER \\ TRAUMA - LITERATURE REVIEW
}

\author{
Grażyna Jarząbek-Bielecka', Małgorzata Mizgier², Witold Kędzia', Michalina Drejza' \\ 'Klinika Ginekologii Katedry Perinatologii i Ginekologii, Uniwersytet Medyczny w Poznaniu \\ ${ }^{2}$ Katedra Nauk Biomedycznych i Nauk o Zdrowiu, Zakład Dietetyki, Zamiejscowy Wydział Kultury Fizycznej w Gorzowie Wlkp., Akademia Wychowania \\ Fizycznego w Poznaniu
}

DOI: https://doi.org/10.20883/ppnoz.2019.67

\begin{abstract}
STRESZCZENIE
Zgodnie z definicją Światowej Organizacji Zdrowia za „dziecko niepełnosprawne" uważa się takie dziecko, które bez specjalnych ulg ani pomocy z zewnątrz jest całkowicie, długotrwale lub w znacznym stopniu niezdolne do uczestnictwa w grupie prawidłowo rozwiniętych i zdrowych rówieśników". Światowa Organizacja Zdrowia wyszczególnia następujące grupy osób niepełnosprawnych: z upośledzeniem umysłowym, z upośledzeniami widzenia, z upośledzeniami w zakresie środków porozumiewania się, z upośledzeniami natury organicznej, z upośledzeniami intelektualnymi, z upośledzeniami emocjonalnymi, z wadami zewnętrznymi, z wadami wewnętrznymi, z problemami związanymi z procesami starzenia się organizmu.

Osoby niepełnosprawne, w tym także dzieci, często są ofiarami przestępców seksualnych. Większe ryzyko stania się ofiarą przemocy istnieje w przypadku dzieci z niepełnosprawnością w porównaniu do młodzieży bez niepełnosprawności.

Dla pedofilów dzieci niepełnosprawne są ofiarami szczególnie łatwymi i bezbronnymi. Dane z piśmiennictwa potwierdzają te spostrzeżenia oraz wskazują, że w grupie ofiar przestępców seksualnych są zarówno dzieci niepełnosprawne intelektualnie jak i somatycznie. Istotna jest znajomość objawów przemocy seksualnej i znajomość postępowania z dzieckiem ofiarą przestępstwa, co w przypadku dzieci niepełnoprawnych jest szczególnie trudne. Jednym z takich objawów są zaburzenia odżywiania.

Wiele aspektów seksualności dzieci i młodzieży nie jest w pełni badanych i realizowanych. Istnieje potrzeba doskonalenia opieki zdrowotnej obejmującej aspekty seksualności osób niepełnosprawnych z wyczuleniem na problem przemocy seksualnej

Tworzenie programów prewencyjnych stanowi wyraz postępu medycyny i wydaje się być niezbędne w tym zakresie.
\end{abstract}

Słowa kluczowe: niepełnosprawność, przestępstwa seksualne, dzieci.

ABSTRACT

According to the definition of the World Health Organization, a "child with a disability" is a child who, without special relief or external assistance, is completely, long-term or largely incapable of participating in a group of well-developed and healthy peers ". The World Health Organization lists the following groups of people with disabilities: with mental retardation, with visual impairment, with disabilities in communication, with organically handicaps, with intellectual disabilities, with emotional disabilities, with external defects, with internal defects, with problems related to the processes of aging of the organism.

People with disabilities, including children, are often victims of sex offenders. There exists a greater risk of becoming a victim of violence among children with disabilities in comparison to young people without disabilities.

For pedophiles, children with disabilities are particularly defenseless victims. Data from the literature confirm these observations and indicate that in the group of victims of sexual offenders, there are both intellectually and somatically disabled children. It is important to know the symptoms of sexual violence and to know how to deal with a child - victim of a crime, which is particularly difficult among children with disabilities. One of these symptoms is eating disorders.

Many aspects of children's sexuality are not fully studied. We need to improve health care covering aspects of the sexuality of disabled people with sensitivity to the problem of sexual violence.

The creation of preventive programs is an expression of the progress of medicine and seems to be necessary.

Keywords: disability, sexual crimes, children.

\section{Wstęp}

Niepełnosprawne dzieci to osoby z bardzo różnymi zaburzeniami i o różnym stopniu upośledzenia czynności fizycznych lub psychicznych. Według Światowej Organizacji Zdrowia za "dziecko niepełnosprawne uważa się takie dziecko, które bez specjalnych ulg ani pomocy z zewnątrz jest całkowicie, długotrwale lub w znacznym stopniu niezdolne do uczestnictwa w grupie prawidłowo rozwiniętych i zdrowych rówieśników". 
Światowa Organizacja Zdrowia wyszczególnia następujące grupy osób niepełnosprawnych:

- $\quad z$ upośledzeniem umysłowym,

- z upośledzeniami widzenia,

- z upośledzeniami w zakresie środków porozumiewania się,

- z upośledzeniami natury organicznej,

- z upośledzeniami intelektualnymi,

- $\quad z$ upośledzeniami emocjonalnymi,

- z wadami zewnętrznymi,

- z wadami wewnętrznymi,

- $\quad$ z problemami związanymi z procesami starzenia się organizmu.

Dzieci z niepełnosprawnością mają zdecydowanie większe ryzyko stania się ofiarami przemocy w porównaniu do młodzieży bez niepełnosprawności $[8,9,10]$.

$\mathrm{Na}$ całym świecie żyje co najmniej 93 miliony dzieci z średnią lub ciężką niepełnosprawnością. Kobiety i dziewczynki są bardziej od mężczyzn narażone na napaść seksualną niezależnie od występowania niepełnosprawności. Różnice między płciami są mniejsze wśród osób z niepełnosprawnością, po części dlatego że sprawcy, którzy zwykle są mężczyznami, mają większy dostęp (przez podejmowanie opieki) do chłopców/mężczyzn z niepełnosprawnością niż dziewczynek/kobiet [8]

Przybliżone oszacowania skali problemu to ważny pierwszy krok w rozwoju programów prewencyjnych. Specjaliści dokonali podziału objawów przemocy seksualnej wobec dzieci:

I. Ostre (wymagana szybka interwencja medyczna):

1. urazy zewnętrznych i wewnętrznych narządów płciowych:

- $\quad$ okolic sromu, krocza: pęknięcie krocza w linii środkowej, mogące rozciągać się od śluzówki pochwy do śluzówki odbytnicy (przedsionek pochwy i odbytnica jako jedna jama pourazowa),

- krwiaki w obrębie błony dziewiczej (wykonane palcem są mniejsze)

- obrażenia okolicy odbytu: zasinienia, pęknięcia odbytu sięgające otaczającej skóry;

2. obrażenia innych okolic ciała: ust i jamy ustnej (zasinienia i krwawe wybroczyny na podniebieniu), kończyn dolnych i górnych;

3. rany powstałe w wyniku ugryzienia;

4. owrzodzenia i rany w przebiegu chorób przenoszonych drogą płciową.

Objawy somatyczne ostre są to zwykle rany zakażone o nierównych brzegach, tłuczone, miażdżone, zasinienia.

UWAGA: Jeżeli dziecko boi się powiedzieć, w jakich rzeczywiście okolicznościach doszło do powstania urazów, a osoba zgłaszająca się z dzieckiem chce zataić prawdę (np. matka zna sprawcę i chce go chronić), to okoliczności powstania urazów podane przez matkę lub dziecko są niespójne lub mało prawdopodobne: „....upadła na ramę od roweru, trzepaka, kant stołu, konar drzewa itp. ..."

II. Przewlekłe:

1. zaburzenia psychoemocjonalne;

2. spokojne, pewne zachowanie się dziecka w trakcie badania ginekologicznego (Postawa taka powinna budzić podejrzenia ginekologa, gdyż dziecko nie wykorzystywane zazwyczaj boi się badania);

3. ubytek błony dziewiczej (lokalizację zmian odnosi się do rozmieszczenia godzin na tarczy zegara); brak błony dziewiczej poniżej hipotetycznej poziomej linii pomiędzy godziną 3. i 6., ubytek lub wygojone pęknięcie, najczęściej na godz. 6.00;

4. trwałe rozszerzenie odbytu do średnicy $>1,5 \mathrm{~cm}$.

UWAGA: W badaniu fizykalnym ogólnym i ginekologicznym u 50-90\% pacjentek nie stwierdzamy żadnych zmian, co wynika z odmiennego sposobu wykorzystywania seksualnego dziecka, np.: dotykanie o podłożu seksualnym, stosunki oralne. Po upływie trzech miesięcy także po stosunkach waginalnych mogą nie pozostać widoczne ślady.

III. Pewne, bezpośrednie:

1. ciąża;

2. choroba przenoszona drogą płciową (STD, sexually transmitted disease);

3. nasienie w pochwie;

4. włosy, krew, ślina, komórki naskórka (w pochwie, w jamie ustnej lub pod paznokciami ofiary), które według wyników analizy molekularnej DNA nie należą do ofiary.

IV. Nieuzasadnione, wątpliwe, mylące niedoświadczonego lekarza.

\section{Przyczyny i skutki oraz najczęstsze ofiary przemocy seksualnej}

Skonstruowany też został rejestr związanych z przemocą seksualną zachowań dzieci i młodzieży $[1,3,5,7,8,9,12$, 13]. Do zachowań tych zaliczono: zaburzenia snu, koszmary i lęki nocne, niezrozumiałe pojawianie się dolegliwości somatycznych, jak np. bólów brzucha, głowy, wymiotów nudności, lęków, fobii, izolowania się od rówieśników i rodziny, zamykania się w sobie, zachowania regresywne, nadpobudliwość psychoruchową, nadmierna lub nieadekwatna do wieku masturbację, problemy z nauką, konflikty z rówieśnikami, objawy depresyjne, myśli, zamiary i próby samobójcze, lęki ujawniane wobec rodzica danej płci, nieoczekiwane, nagłe zainteresowanie się seksem, własnym 
ciałem, a także życiem seksualnym i ciałem rodziców oraz innych osób, a u niektórych ofiar konsekwencją przemocy seksualnej doznanej w dzieciństwie mogą być zaburzenia odżywiania (EDs, eating disorders) o różnej postaci i nasileniu, co przez niektórych autorów traktowane jest jako rodzaj swoistego "samookaleczania się" $[3,8,9]$.

Autorzy pracy Language Impairment and Sexual Assault of Girls and Women: Findings from a Community Sample wskazują na spostrzeżenie innych autorów, że niestety, zarówno dorośli, jak i dzieci bywają ofiarami przemocy i napaści, również seksualnej; kobiety i dziewczynki stanowią zdecydowaną większość ofiar zarówno wśród osób z niepełnosprawnością, jak i bez. Problemy komunikacyjne zostały zidentyfikowane również przez tych autorów jako jeden z czynników podatności osób z niepełnosprawnością na napaści seksualne. Niestety, niewiele badań uwzględnia upośledzenie funkcji językowych jako czynnika sprzyjającego napaści seksualnej. Badanie autorów Language Impairment and Sexual Assault of Girls and Women: Findings from a Community Sample bierze pod uwagę grupę dzieci $z$ upośledzeniem funkcji językowych i/lub mowy do lat 25. Historia napaści seksualnej jest tu oceniona przez dwu-pytaniowy Composite International Diagnostic Interview Posttraumatic Stress Disorder module. Kobiety z upośledzeniem funkcji językowych ( $n=33$ ) zgłaszały częściej niż kobiety bez takiej niepełnosprawności $(n=59)$ napaść/przemoc seksualną. Biorąc pod uwagę kontrolę, status socjoekonomiczny, należy stwierdzić, że napaść seksualna była korelowana z częstszym występowaniem chorób psychicznych i gorszym funkcjonowaniem w społeczeństwie [1].

Niewiele badań mówi o związkach problemów z komunikacją, mową i poziomem umiejętności językowych a wzrostem ryzyka napaściseksualnej. Natomiast, jak zaobserwowano, zaburzenia funkcji językowych mogą zwiększać podatność na przemoc seksualną w wielu aspektach. Ograniczone zdolności komunikacji mogą stanowić przeszkodę w ujawnieniu czynu. Zaburzenia te są korelowane z mniejszą wydajnością komunikacji. Mogą też stanowić barierę psychiczną, by młode ofiary napaści seksualnej mogły mówić na temat swoich historii [1].

Kobiety w wieku 25 lat, które doświadczyły przemocy seksualnej, częściej zapadają na choroby psychiczne, w szczególności na nerwice. Zauważono również zwiększone występowania zaburzeń afektywnych i stresu pourazowego z pozytywnym wywiadem w kierunku przemocy seksualnej, zauważa się również częstsze występowanie depresji [1]

Raz jeszcze warto tu podkreślić znaczenie zaburzeń jedzenia jako objawów przemocy seksualnej także u osób niepełnosprawnych. W konsekwencji przeżytej traumy objawy zaburzeń odżywiania mogą pojawić się zarówno u dziewcząt, jak i u chłopców, jednak częściej dotyczą płci żeńskiej - dotyczy to także dzieci niepełnosprawnych. Opisywane są zaburzenia, które aktualnie nie występują w obowiązujących klasyfikacjach. Do nich należą tzw. zespoły bariofobii, czyli nietypowe zaburzenia odżywiania, podczas których pacjenci nagle niepokojąco chudną bądź nadmiernie tyją, uzależniają się od słodyczy, towarzyszy temu lęk przed otyłością, a także ortoreksja, czyli nadmierne obsesyjne przywiązanie do spożywania zdrowej żywności. U części osób pojawiają się objawy jadłowstrętu psychicznego, bulimii psychicznej oraz innych ujętych w międzynarodowych klasyfikacjach DSM-5 oraz ICD-10 zaburzeń odżywiania. Najbardziej znanym zaburzeniem z tej grupy jest jadłowstręt psychiczny (anorexia nervosa, AN), charakteryzujący się ekstremalnym ograniczeniem przyjmowania pożywienia i nietypowym obsesyjnym kontrolowaniem oraz utrzymywaniem niskiej masy ciała. Bulimia psychiczna (bulimia nervosa, BN) może być opisana jako nadmierne przyjmowanie dużych ilości pożywienia w krótkim okresie czasu (binging) z towarzyszącymi zachowaniami kompensacyjnymi prowadzącymi do zmniejszenia masy ciała (przeczyszczanie się, wymioty). W obu zaburzeniach pacjenci dążą do kontroli masy ciała, przy czym osoby z AN osiągają niską i bardzo niską masę ciała, a pacjenci z BN mają najczęściej prawidłową masę ciała Kolejnym z grupy EDs jest zaburzenie odżywiania z epizodami niekontrolowanego objadania się (binge eating disorder, BED). Pacjenci z BED kompulsywnie przyjmują duże ilości pożywienia do momentu poczucia problemów żołądkowych związanych z przejedzeniem się, czemu nie towarzyszą działania mające na celu zrekompensowanie napadu objadania się, co w konsekwencji prowadzi do nadwagi lub otyłości. Niektórzy badacze sugerują, że wskaźnik częstości zachorowania na EDs znacząco wzrósł w czasie ostatnich 10 lat. W diagnozowaniu ofiar przemocy seksualnej- także osób niepełnosprawnych zawsze należy zwrócić uwagę na problem odżywiania się. Jest to ważny objaw zważywszy na częste zaburzenia intelektualne związane z problemami lingwistycznymi - skrzywdzone dziecko niepełnosprawne istotnie rzadko mówi wprost o traumie $[1,3,5,7,8,9,12,13]$

Zwiększone ryzyko przemocy seksualnej wśród dziewczynek i kobiet z zaburzeniami lingwistycznymi niesie implikacje dla profesjonalistów i badaczy pracujących z młodzieżą z tą niepełnosprawnością: muszą być świadomi występowania takiego ryzyka. Autorzy pracy Language Impairment and Sexual Assault of Girls and Women: Findings from a Community Sample, podobnie jak autorzy innych doniesień, wskazują, że powinny być się wprowa- 
dzone rutynowe badania w kierunku występowania przestępstw seksualnych i że nadal brakuje dobrze skonstruowanych metod badań dzieci niepełnosprawnych - ofiar przemocy seksualnej, a dane na temat występowania przemocy wśród dzieci i młodzieży z niepełnosprawanościami są niedostateczne [1].

Autorzy artykułu "Prevalence and risk of violence against children with disabilities: a systematic review and meta-analysis of observational studies" podjęli metaanalizę i dokonali przeglądu systematycznego występowania i czynników ryzyka przemocy wobec dzieci niepełnosprawnych. Dla celów pracy przeanalizowano 12 elektronicznych baz danych, żeby zidentyfikować badania między 1 stycznia 1990 r. do 17 sierpnia 2010 r. z estymatami występowania przemocy wobec dzieci (osób poniżej 18 roku życia) z niepełnosprawnością i ryzyka zostania ofiarą takiej przemocy w porównaniu z dziećmi bez niepełnosprawności. 17 badań zostało wybranych z 10663 referencji. Podsumowania z 16 badań dostarczyły danych do metaanalizy oraz analizy występowania, a także 11 oceniło ryzyko. Wyniki przeglądu systematycznego potwierdziły dane przedstawiane przez innych autorów, że dzieci z niepełnosprawnością są zdecydowanie bardziej predysponowane do stania się ofiarą przemocy niż dzieci bez niepełnosprawności [5]. Jednakże ciągły niedostatek silnych dowodów - wskutek braku dobrze zaprojektowanych badań, niskie standardy pomiaru niepełnosprawności i przemocy, niedostateczna ocena, czy przemoc poprzedza rozwój niepełnosprawności - pozostawia braki w wiedzy, które muszą zostać zaadresowane.

W opracowywaniu raportów na temat przemocy wobec dorosłych z niepełnosprawnościami dominują kraje wysoko rozwinięte - USA, Europa. Brakuje jednak danych z innych rejonów świata, w których wskaźnik populacji z niepełnosprawnościami, wskaźniki przemocy i niskie wsparcie ze strony infrastruktury państwa jest zdecydowanie bardziej widoczny.

Mimo że dzieci z niepełnosprawnościami są bardziej podatne na różne typy przemocy, badania skupiają się na skrajnym maltretowaniu dzieci (przemoc fizyczna, emocjonalna i seksualna, zaniedbanie). Rozpoznanie różnych rodzajów przemocy (nie tylko skrajne maltretowanie) wobec dzieci z niepełnosprawnościami może sięgać daleko dalej niż wybrane wyniki analizowanych zjawisk i ich interpretacji [5]

\section{Ocena objawów i zachowań dziecka z niepełnosprawnością intelektualną powstałych na skutek molestowania}

Ocena dziecka z niepełnosprawnością intelektualną wymaga właściwej oceny objawów i zachowań, które po- wstały na skutek molestowania. Badanie w kierunku wykluczenia molestowania seksualnego wymaga obowiązkowego rozeznania w temacie molestowania. Celem pracy Koetting C. i wsp. pod tytułem "Nurse practitioner knowledge of child sexual abuse in children with cognitive disabilities" było zbadanie poziomu wiedzy na temat objawów i symptomów molestowania dzieci z zaburzeniam funkcji poznawczych. Badaniu została poddana 43 grupa z dwóch organizacji zrzeszających pielęgniarki. Dane z ankiet na temat wiedzy o molestowaniu seksualnym przeprowadzonych wśród pielęgniarek pokazały brak w umiejętności identyfikowania części niedojrzałych genitaliów dziewczynek. Według obserwacji oraz tej publikacji wiedza pielęgnierek na temat opieki na dziećmi niepełnosprawnymi - ofiarami przemocy seksualnej jest niestety niewystarczająca. Większość ankietowanych pielegniarek nie badało genitaliów przy regularnych badaniach przedmiotowych. Nie czuły się kompetentne, żeby takie badania przeprowadzać i nie miały wiedzy na temat oficjalnych stanowisk organizacji zrzeszających pielęgniarki w zakresie oceny chorej przy podejrzeniu molestowania seksualnego. $67 \%$ pielęgniarek pediatrycznych bada genitalia dziewczynek, które jeszcze nie zaczęły dojrzewać u ponad połowy swoich podopiecznych, kiedy zapytane o identyfikację błony dziewiczej i wejścia pochwy 6-letniej dziewczynki tylko 60\% potrafiło wskazać poprawną odpowiedź [6].

Dzieci z niepełnosprawnością intelektualną są molestowane 2-3 razy częściej niż dzieci bez tej niepełnosprawności. Dzieci te są bardziej podatne na molestowanie, ponieważ nie są one zdolne zwerbalizować opisu zdarzenia oraz nie rozumieją, które czyny mogą być odbierane jako molestowanie [5].

Ofiary molestowania seksualnego są predysponowane dwa razy częściej do zakażenia chorobą przenoszona drogą płciową, a także trzy razy częściej zgłaszają więcej niż jedną chorobę prznoszoną drogą płciową [6]

Tylko 5\% ofiar molestowania seksualnego posiada fizyczne znamiona mogące mocno sugerować molestowanie. Jest zatem tak samo ważne posiadanie wiedzy na temat regularnego badania zarówno dzieci z niepełnosprawnością intelektualną, jak i dzieci bez tej niepełno sprawności.

Zachowania pojawiające się częściej to wycofanie, skłonności do samookaleczania, niewłaściwe komentarze o treści seksualnej, nietypowe komentarze na temat członków rodziny i domu [6].

Molestowane dzieci z autyzmem mogą mieć wzrost zachowań nietypowych lub nawet rozwój nowych zachowań. Niemówiące dzieci z autyzmem mogą próbować ujawnić przemoc wobec nich poprzez zachowania samo- 
okaleczające, jednak poprzez podobieństwo do podstawowych zachowań autystycznych zachowania takie mogą zostać nierozpoznane [6].

Zarówno dzieci z niepełnosprawnością intelektualną, jak i bez, mogą prezentować zachowania związane z molestowaniem i przemocą seksualną. Pielęgniarki powinny mieć wiedzę na temat tych objawów. Istnieje wiele akcji, szkoleń, badań, których celem jest poszerzanie wiedzy dotyczącej problemu przemocy seksualnej. Uwzględniają też zagadnienie dzieci niepełnosprawnych będących ofiarami przestępstw seksualnych. Do badań nad dziećmi z niepełnosprawnością został dostosowany Kwestionariusz CSAFKA (The Child Sexual Abuse Findings Knowledge Assessment).

Jemta L. i wsp. zwracają uwagę, że wiele aspektów seksualności dzieci i młodzieży nie jest w pełni badanych. Zauważają oni potrzebę doskonalenia opieki zdrowotnej zajmującej się seksualnością osób niepełnosprawnych i wyczuleniem jej na problem przemocy seksualnej [4]. Celem ich pracy było opisanie doświadczeń intymnych, aktywności seksualnej oraz ekspozycji na przemoc seksualną pośród dzieci i młodzieży z niepełnosprawnością ruchową oraz relacją danych socjodemograficznych z charakterystyką niepełnosprawności i warunkami bytowymi. Autorzy tego opracowania przeprowadzili 141 zaprojektowanych wywiadów z dziećmi i młodzieżą w wieku od 7-18 lat z niepełnosprawnoscią ruchową. Badano relacje intymne i seksualność, dane socjoekonomiczne, charakterystykę niepełnosprawnosci i samopoczucie. Około połowa badanych dzieci zgłaszała bliskie relacje (miała "chłopaka", "dziewczynę"), 20\% obecnie przebywa w związkach. 15\% młodzieży zgłasza relacje seksualne. W badanej grupie nie rozpoznawano dysfunkcji seksualnych. 15\% miało obawy dotyczące ich przyszłych stosunków seksualnych, zwłaszcza związanych z zaburzeniami ruchowymi. Warte podkreślenia jest, że 7\% badanych zgłosiło wykorzystywanie seksualne - dotyczyło to grupy wiekowej 13-18. Cechy socjodemograficzne i związane z niepełnosprawnością miały marginalny wpływ na doświadczenia seksualne [4].

Według Jemta L. i wsp. Stevens i wsp. również prowadzili badania dotyczące seksualności niepełnosprawnych: 1/3 młodzieży w wieku 13-16 z niepełnosprawnością była "na randce", ale ci młodzi ludzie stwierdzali, że rodzice unikają rozmowy na temat seksualności; w ich opinii rodzice dzieci niepełnosprawnych, nie wierzą, że mogą one wiązać się w relacjach seksualnych. Pytania na temat doświadczeń seksualnych w pracy Stevensa i wsp. były zadawane tylko dzieciom od lat 13 wzwyż. Pytania na temat szczegółów relacji zadawano osobom będącym w związkach. Autorzy tego doniesienia zadawali też pytania na temat dysfunkcji seksualnych: zaburzeń erekcji, anorgazmii, przedwczesnego/opóźnionego wytrysku oraz obniżonego libido. Jeżeli odpowiedzi były pozytywne, pytano, czy dana osoba ma się do kogo zwrócić z problemem [4, 14].

\section{Podsumowanie}

Wyniki badań przedstawione w niniejszym opracowaniu, potwierdzają obserwacje własne i doniesienia innych autorów o konieczności doskonalenia opieki zdrowotnej nad osobami niepełnosprawnymi obejmującej też opiekę seksuologiczną $[2,11]$.

\section{Oświadczenia}

Oświadczenie dotyczące konfliktu interesów

Autorzy deklarują brak konfliktu interesów.

\section{Źródła finansowania}

Autorzy deklarują brak źródeł finansowania.

\section{Piśmiennictwo}

1. Brownlie EB, Jabbar A, Beitchman J, Vida R, Atkinson L. Language Impairment and Sexual Assault of Girls and Women Findings from a Commuity Sample. J. Abnorm. Child. Psy chol., 2007; 35(4): 618-626.

2. Jarząbek-Bielecka G, Radomski D, Bielecki M. O opiece ginekologicznej i seksuologicznej nad pacjentką niepełnospraw ną ( z uwzględnieniem poradnictwa aptekarskiego). w: Na uka o płci. Zagadnienia wybrane. Pod red. Grażyny Jarząbek Bieleckiej. Poznań, 2012.

3. Jarząbek-Bielecka G, Sowińska-Przepiera E, Mizgier M, PisarskaKrawczyk M, Kędzia W. Eating disorders as a result of sexual abuse of children - endokrynologial and sexuological aspects Endokr. Pediat., 2017; 16( 2): 133-136.

4. Jemta L, Fugl-Meyer KS, Oberg K. On intimacy, sexual activities and exposure to sexual abuse among children and adolescents with mobility impairment. Acta Pædiatrica., 2008; 97: 641-646

5. Jones LA, Bellis M, Wood S, Hughes K, McCoy E, Eckley L, Bate GS, Mikton Ch, Shakespeare T, Officer A. Prevalence and risk of violence against children with disabilities: a systematic review and meta-analysis of observational study http//www who.int/disabilities/publications/violence_children_lancet pdf (10.02.2018)

6. Koetting CJ, Fitzpatrick J, Lewin L, Kilanowski J. Nurse practitioner knowledge of child sexual abuse in children with cognitive disabilities. J. Forensic. Nurs. 2012; 6, 8(2): 72-80.

7. Łabęcka M, Jarząbek-Bielecka G, Lorkiewicz-Muszyńska D. Przestępstwa seksualne - wybrane przypadki. Sexual offences - selected cases. Ginek. Pol. 2013; 84(4): 309-313.

8. Marzec-Holka K. Przemoc seksualna wobec dziecka: studium pedagogiczno-kryminologiczne. Wydawnictwo Uczelniane WSP, Bydgoszcz 1997: 16

9. Morse O, Shapira L. The Relationship Between Sexual Abuse/ Trauma and Eating Disorders. Materiały Ośrodka New Realities Eating Disorders Recovery Centre.

10. Projekt Globalnego Planu Działania WHO na rzecz niepełnosprawności na lata 2014-2021: Lepsze zdrowie dla wszystkich osób niepełnosprawnych. http://www.pfron.org.pl/download/5/560/04WHOpl (10.02.2018).

11. Radomski D, Jarząbek-Bielecka G, Sowińska-Przepiera E, Milewczyk P. Problem opieki ginekologicznej nad dziewczętami 
i kobietami niepełnosprawnymi. Ginek. Prakt. 2010; 18(2): 36-42.

12. Sowińska-Przepiera E, Andrysiak-Mamos E, Jarząbek-Bielecka G, Walkowiak A, Syrenicz A. Wykorzystywanie seksualne dziewcząt [-] aspekty medyczne, prawne i etyczne. Sexual abuse of girls [-] aspects of medical, legal and ethical. Klin. Pediat., 2014, 22, [zesz. spec.] Algorytmy w pediatrii: 7112-7116.

13. Sowińska-Przepiera E, Jarząbek-Bielecka G, Andrysiak-Mamos E, Syrenicz A, Friebe Z, Kędzia W, Pawlaczyk M. Wybrane aspekty prawne $\mathrm{W}$ ginekologii wieku rozwojowego. Legal aspects in pediatric and adolescent gynecology. Ginek. Pol. 2013; 84(2): 131-136.

14. Stevens SE, Steele CA, Jutai JW, Kalnins IV, Bortolussi JA, Biggar WD. Adolescents with physical disabilities: somepsychosocial aspects of health. J. Adolesc. Health. 1996; 19: 157-164.
Zaakceptowano do edycji: 15.12.2019

Zaakceptowano do publikacji: 15.02.2020

\author{
Adres do korespondencji: \\ Małgorzata Mizgier \\ Akademia Wychowania Fizycznego w Poznaniu \\ Katedra Nauk Biomedycznych i Nauk o Zdrowiu \\ Zakład Dietetyki, Zamiejscowy Wydział Kultury Fizyczne \\ w Gorzowie Wielkopolskim \\ ul. Estkowskiego 13 \\ 66-400 Gorzów Wlkp \\ tel. 603966337 \\ e-mail:m.mizgier@awf-gorzow.edu.pl
}

